\title{
Antioxidative and digestion enzyme inhibitory activity of Ganoderma lucidum depends on the extraction solvent
}

\author{
Ok Soo Joo ${ }^{1}$, Chung Eun Hwang ${ }^{1}$, Su Young Hong ${ }^{2}$, Eui Cheol Sin ${ }^{1}$, \\ Sang Hae $\mathrm{Nam}^{1}$, Kye Man Cho ${ }^{1 *}$ \\ ${ }^{1}$ Department of Food Science, Gyeongnam National University of Science and Technology, Jinju 52725, Korea \\ ${ }^{2}$ Food Science Research Institute, Kolmar BNH Inc, Sejong 30003, Korea
}

\section{추출용매에 따른 영지버섯(Ganoderma lucidum)의 항산화 및 소화효소 저해활성}

\author{
주옥수 ${ }^{1} \cdot$ 황정은 $^{1} \cdot$ 홍수영 $^{2} \cdot$ 신의철 $^{1} \cdot$ 남상해 $^{1} \cdot$ 조계만 ${ }^{1 *}$ \\ ${ }^{1}$ 경남과학기술대학교 식품과학부, ${ }^{2}$ 콜마비앤에이치(주) 식품과학연구소
}

\begin{abstract}
This study investigated the nutritional properties and biological activities of Ganoderma lucidum (GL). The round type of GL contained higher carbohydrate content, while the Nokgak type of GL contained higher crude ash, crude fat, and crude protein content. The most abundant amino acid, fatty acid, mineral, and soluble vitamin observed were valine (round type: $11.90 \mathrm{mg} / \mathrm{g}$ and Nokgak type: $17.18 \mathrm{mg} / \mathrm{g}$ ), linoleic acid (round type: $47.56 \%$ and Nokgak type: $75.68 \%$ ), potassium (round type: $116.50 \mathrm{mg} / 100 \mathrm{~g}$ and Nokgak type: $184.36 \mathrm{mg} / 100 \mathrm{~g}$ ), and vitamin $\mathrm{B3}$ (round type: $1.78 \mathrm{mg} / 100 \mathrm{~g}$ and Nokgak type: $1.81 \mathrm{mg} / 100 \mathrm{~g}$ ), respectively. In addition, the $\beta$-glucan content were $34.15 \mathrm{~g} / 100 \mathrm{~g}$ (round type) and $30.07 \mathrm{~g} / 100 \mathrm{~g}$ (Nokgak type). The GL $70 \%$ ethanol extract at $40^{\circ} \mathrm{C}$ showed higher radical scavenging as well as carbohydrate and lipid enzyme inhibition than other conditions. At $1 \mathrm{mg} / \mathrm{mL}$ of treatment with the $70 \%$ ethanol extract at $40^{\circ} \mathrm{C}$ of round type GL, the DPPH, ABTS, hydroxyl radical scavenging, and a-glucosidase, a-amylase, and pancreatic lipase inhibition activities obtained were approximately 92.85, 99.74, $58.09,89.68,44.68$, and $67.56 \%$, respectively.
\end{abstract}

Key words : Ganoderma lucidum, ethanolic extracts, antioxidant activity, a-glucosidase inhibitory activity, pancreatic lipase inhibitory activity

\section{서 론}

21세기 생활수준의 향상과 의학기술의 눈부신 발전으로 인간의 평균수명이 증가된 고령화 사회로 접어들면서 건강 하게 나이를 먹는 것에 대한 욕구가 강해지고 있으며, 이에 따라 기능성식품과 천연물에 대한 관심이 높아지고 있다 (1). 한편 서구식 식생활습관이 증가함에 따라 비만에서

*Corresponding author. E-mail : kmcho@gntech.ac.kr Phone : 82-55-751-3272, Fax : 82-55-751-3279

Received 31 January 2018; Revised 17 February 2018; Accepted 20 February 2018.

Copyright (c) The Korean Society of Food Preservation. All rights reserved.
유래된 대사성 질환 환자들이 날로 증가하고 있다. 비만은 과다한 지방이 축적되어 다양한 원인에 의해 나타나고 대사 성 질환인 고지혈증, 고혈압 및 당뇨에 직접적인 영향을 미치고 있다. 당뇨병은 고혈당을 특징으로 하는 일련의 대 사성 질환으로 삶의 질을 떨어뜨리는 1 위 질환으로서, 인슐 린 의존형인 제 1 형과 비의존형인 제 2 형 당뇨로 분류되고 우리나라의 경우 제 2 형 당뇨가 대부분을 차지한다(2). 현재 비만 및 당뇨의 약물치료제는 독성문제와 환자의 내성문제 등 많은 부작용이 대두되고 있어, 천연물 소재를 이용하여 부작용을 최소화 한 기능성 소재 개발에 관한 연구가 활발 히 수행되고 있다 $(2,3)$. 특히 당뇨병과 항산화 작용이 밀접 한 관계가 있는 것으로 알려지면서 약용 식물 혹은 약용 버섯 추출물에 대한 항산화 및 항당뇨 연구가 활발히 진행 
되고 있다(3).

버섯은 분류학상 고등균류로서 당질, 단백질, 무기질 및 비타민 등의 각종 영양소를 골고루 함유하고 있을 뿐만 아니라 독특한 맛과 풍미를 가지고 있으며, 생리활성물질 을 생산함으로써 식품학적으로 가치가 높다 $(1,4)$. 버섯의 식품학적 기능은 영양학적 가치에 의한 1 차적 기능, 기호성 에 따른 2 차적 기능 및 인체 내의 다양한 생리조절 기능에 관여하는 3 차적 기능으로 구분할 수 있다(4). 버섯의 생리조 절 기능으로는 항산화 효과(4,5), 항암 효과(4), 항비만 효과 (6-8) 및 항당뇨 효과(9) 등의 활성을 가지고 있다.

영지버섯(Ganoderma licidum)은 만년초 혹은 불로초로 불리며 열대, 아열대 및 온대 지방을 포함한 아시아, 유럽 및 북미주 등 전 세계적으로 분포하고 있는 목재부후균이다 $(10,11)$. 영지버섯은 예로부터 한국, 중국 및 일본 등 아시아 에서 약용버섯으로 취급되어 왔으며, 현재에는 항산화, 항 암, 항종양, 항고혈압, 항비만 및 항당뇨 등과 관련된 여러 생리활성 효과와 유효성분이 과학적으로 규명되고 있다 $(11,12)$. 특히 영지버섯에는 polysaccharide이외에 tritepene, nucleoside, steroid, fatty acid, alkaloid, 단백질, 무기질 및 비타민 등 다양한 물질들이 함유되고 있고 그 중 고분자 물질(polysaccharide)과 저분자 물질(tritepene 등)로 구분할 수 있다. 한편 고분자 물질 중 대표적인 $\beta$-glucan은 포도당 중합체로서 인체의 비특이적 면역반응으로 정상세포 면역 기능을 활성화시켜 암세포 증식과 재발을 억제하고 혈당강 화 및 혈중 콜레스테롤 감소 효과가 우수하며, 지질대사를 개선하여 체지방 형성과 축적을 억제함으로써 항비만 효과 를 가지고 있는 것으로 보고되어 있고(13), 저분자 물질은 항염증, 항산화, 간세포보호, 항알레르기, 항고혈압, 콜레스 테롤 저하 및 혈소판 응집 저해 등의 활성이 있다(10).

따라서 본 연구에서는 자실체 생김새가 다른 원형영지버 섯 및 녹각영지버섯의 일반성분, 아미노산, 지방산, 무기질, B-glucan 및 수용성 비타민 함량을 조사하였다. 또한 에탄올 추출조건(에탄올 농도와 추출온도)에 따른 총 phenolics 및 flavonoids 함량, 라디칼 활성 및 탄수화물과 지방 분해효소 의 저해능을 평가하였다.

\section{재료 및 방법}

\section{실험 재료, 시약 및 기기}

본 실험에 사용한 원형 및 녹각영지버섯(Genoderma Lucidum)은 전라북도 임실영지버섯영농조합법인으로부터 제공받았으며 경상남도 농업기술원 버섯과로부터 검증 받 은 후 사용하였다. 수용성 비타민(thaimine, riboflavin 및 niacin), Folin-Cialteu phenol, diethylene glycol, 2-deoxyribose, 2,2-diphenyl-1-picrylhydrazyl(DPPH), 2,2'-azino-bis(3ethylbenzthiazoline-6-sulphonic acid) diammonium salt(ABTS),
p-nitrophenyl-a-D-glucopyranoside( $p$-NPG) 및 $p$-nitrophenylbutyrate( $p$-NPB)는 Sigma-Aldrich(St. Louis, MO, USA)에서 구입하여 사용하였다. a-Glucosidase, a-amylase 및 pancreatic lipase 역시 Sigma-Aldrich에서 구입하여 사용하였고 Megazyme Kit(Mushroom and Yeast $\beta$-glucan Assay Procedure K-YBGL) 은 Megazyme International Ireland(Bray, Wicklow, Ireland)에 서 구입하였다. HPLC- grade $\mathrm{H}_{2} \mathrm{O}$, methanol, acetonitrile 및 glacial acetic acid는 Fisher Scientific(Fairlawn, NJ, USA)에 서 구입하였다. 이 외에 분석을 위한 시약은 필요에 따라 특급 혹은 1 급을 구입하여 사용하였다.

분광광도계는 Spectronic $2 \mathrm{D}$ (Spectronic $2 \mathrm{D}$, Thermo Co., Petaluma, CA, USA)를 사용하여 유효성분 물질(phenolics 및 flavonoid), 항산화 및 효소 저해활성을 측정하였다. Gas chromatography(GC)는 Agilent GC 7890 series(Agilent Co., Forest Hill, Australia)를 사용하여 지방산을 분석하였다. High pressure liquid chromatography(HPLC)는 Agilent HPLC 1200 series(Agilent Co.,)를 사용하여 수용성 비타민 함량을 분석하였다. 한편 무기질 함량 분석은 inductively coupled plasma spectrometer(ICP)와 iCAP6300 Duo ICP spectrometer(Thermo Scientific, London, UK)를 사용하였고 아미노산 함량 분석은 자동 아미노산 분석기 $(\mathrm{L}-8900$, Hitachi, Tokyo, Japan)를 사용하였다.

\section{일반성분 분석}

영지버섯의 일반성분은 식품공전의 일반성분 분석법 (14)에 준하여 실시하였다. 즉, 수분 및 회분 함량은 상압가 열건조법과 건열회화법으로 측정하였으며 조지방 및 조단 백 함량은 Soxhelt과 Kjeldahl법으로 측정하였다. 탄수화물 함량 계산은 100 에서 상기 각 성분의 합을 뺀 값으로 표시하 였다.

아미노산 및 지방산 분석

아미노산 분석은 Cho 등(12)의 방법을 약간 변경하여 수행하였다. 시료 $100 \mathrm{mg}$ 을 정확히 시험관에 칭량하고 여 기에 $6 \mathrm{~N} \mathrm{HCl}$ 을 $3 \mathrm{~mL}$ 가하여 $110^{\circ} \mathrm{C}$ 에서 24 시간 동안 산 가수분해 시켰다. 그 후 glass filter로 여과하고 얻은 여액을 $60^{\circ} \mathrm{C}$ 에서 감압 농축하여 $\mathrm{HCl}$ 과 물을 완전 증발시켰다. 농축 된 시료는 soduim citrate buffer(pH 2.2) $2 \mathrm{~mL}$ 를 첨가하여 용해 후 $0.45 \mu \mathrm{m}$ membrane filter(Dismic-25CS, Toyoroshikaisha Ltd., Tokyo, Japan)로 여과한 여액을 자동 아미노산 분석기 를 사용하여 분석하였다.

지방산 분석은 Shin 등(15)의 방법에 준하여 수행하였다. 지방산 전처리는 각각의 버섯 분말 $1 \mathrm{~g}$ 에 $0.5 \mathrm{~N}$ 메탄올성 $\mathrm{NaOH} 3 \mathrm{~mL}$ 를 가해 $100^{\circ} \mathrm{C}$ 의 heating block을 이용하여 약 10 분간 가온하여 지방산과 글리세롤을 가수분해 시켰다. 가수분해에 이어 삼불화붕소 $\left(\mathrm{BF}_{3}\right) 2 \mathrm{~mL}$ 를 가하여 교반한 후 30 분간 다시 가온함으로써 지방산의 메틸에스테르화를 
진행하였다. 반응이 끝난 후 이소옥탄 $1 \mathrm{~mL}$ 를 첨가하고 격렬히 흔든 후 원심분리 및 이소옥탄층만을 회수하여 무수 황산나트륨과 함께 탈수한 뒤 $0.45 \mu \mathrm{m}$-membrane filter (Dismic-25CS)로 여과하여 GC를 이용하여 분석하였다.

\section{무기질 분석}

무기질 함량은 식품공전의 무기질 분석법(14)에 준하여 수행하였다. 즉 영지버섯 분말 $0.5 \mathrm{~g}$ 에 $70 \%$ 질산 용액 8 $\mathrm{mL}$ 를 첨가하여 microwave로 분해하였다. 그 후 $50 \mathrm{~mL}$ 의 멸균증류수로 정용하여 시험용액을 조제한 후 ICP(inductively coupled plasma)로 분석하였다. 한편 나트륨은 $550-600^{\circ} \mathrm{C}$ 회화로에서 회화한 후 $30 \mathrm{~mL}$ 의 $3 \%$ 질산 용액으로 정용하 여 ICP로 분석하였다.

\section{$\beta$-glucan 분석}

영지버섯의 $\beta$-glucan 함량 또한 식품공전법(14)에 따라 Megazyme Kit를 이용하여 분석하였다. $100 \mathrm{mg}$ 에 $37 \% \mathrm{HCl}$ $1.5 \mathrm{~mL}$ 를 가하고 $30^{\circ} \mathrm{C}$ 에서 45 분간 교반한 후 3 차 증류수 $10 \mathrm{~mL}$ 를 가하고 $100^{\circ} \mathrm{C}$ 에서 다시 2시간 교반하였다. 이 반응 액을 상온에서 식힌 후 $2 \mathrm{~N} \mathrm{KOH} 10 \mathrm{~mL}$ 를 가하여 혼합하고 이 혼합물에 $0.2 \mathrm{M}$ sodium acetate buffer(pH 5.0)를 가하여 $100 \mathrm{~mL}$ 로 정량한 후 $1,500 \times \mathrm{g}$ 에서 10 분간 원심분리하여 상등액을 얻었다. 상등액 $0.1 \mathrm{~mL}$ 에 exo-1,3-ß-glucanase(20 $\mathrm{U} / \mathrm{mL})$ 와 $\beta$-glucosidase $(4 \mathrm{U} / \mathrm{mL})$ 용액 $0.1 \mathrm{~mL}$ 를 가하고 $40^{\circ} \mathrm{C}$ 에서 60 분간 반응 후 glucose oxidase/peroxidase 시약을 3 $\mathrm{mL}$ 를 넣고 $40^{\circ} \mathrm{C}$ 에서 20 분간 반응시킨 후 $510 \mathrm{~nm}$ 파장에서 흡광도를 측정하였다. 이때 $\beta$-glucan 함량은 glucose를 이용 한 표준용액으로부터 값을 산출하였다.

\section{수용성 비타민 분석}

비타민은 식품공전의 비타민 분석법(14)에 준하여 시료 전처리 후 HPLC로 분석하였다. 분석 칼럼은 capcell-pak $\mathrm{C}_{18}(4.6 \times 150 \mathrm{~mm}, 5 \mu \mathrm{m})$ 및 capcell-pak $\mathrm{C}_{18} \mathrm{MG}(4.6 \times 250 \mathrm{~mm}$, $5 \mu \mathrm{m})$ 을 사용하였고 이동상 용매 $\mathrm{A}$ 는 비타민 $\mathrm{B} 1$ 의 경우 $10 \mathrm{mM} \mathrm{NaH}_{2} \mathrm{PO}_{4} / 0.15 \mathrm{M} \mathrm{NaClO}_{4}$ in $\mathrm{H}_{2} \mathrm{O}$, 비타민 $\mathrm{B}_{2}$ 는 10 $\mathrm{mM} \mathrm{NaH} \mathrm{PO}_{4}$ in $\mathrm{H}_{2} \mathrm{O}(\mathrm{pH} 5.5)$ 및 비타민 $\mathrm{B}_{3}$ 는 $5 \mathrm{mM}$ sodium hexanesulfonate $/ 0.1 \%$ acetic acid in $\mathrm{H}_{2} \mathrm{O}$ 를 사용하였고, 이동

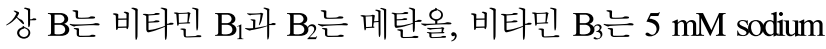
hexanesulfonate/0.1\% acetic acid in $\mathrm{H}_{2} \mathrm{O}$ :메탄올(35:65)을 사 용하였다. 시료는 5-10 $\mu \mathrm{L}$ 를 주입하였으며 이동상 속도는 $35-40^{\circ} \mathrm{C}$ 에서 $0.5-1.0 \mathrm{~mL} / \mathrm{min}$ 로 유지하였다. 검출기는 fluorescence 및 photodiode array(Agilent Co.)를 사용하였 다. 검출 파장은 $450 \mathrm{~nm}$ (비타민 $\mathrm{B} 1), 530 \mathrm{~nm}$ (비타민 $\mathrm{B}_{2}$ ) 및 $260 \mathrm{~nm}$ (비타민 $\mathrm{B}_{3}$ )에서 정량하였다.

\section{영지버섯 건조물 및 에탄올 추출물 제조}

에탄올 추출물 제조는 각각의 영지버섯 분말 $10 \mathrm{~g}$ 에 $30 \%$,
$50 \%, 70 \%$ 및 $95 \%$ 에탄올을 $200 \mathrm{~mL}$ 씩 가하여 $40^{\circ} \mathrm{C}$ 및 $70^{\circ} \mathrm{C}$ 에서 4시간 동안 $600 \mathrm{rpm}$ 속도를 유지하여 추출하였다. 동일한 조건으로 2회 반복 추출하여 모은 후 여과지(No.2, Whatman, Tokyo Roshi Kaisha, Ltd., Tokyo, Japan)로 여과 하여 모은 후 여과액을 감압농축기(EYELA, Tokyo, Rikakikai Co., Tokyo, Japan)를 이용하여 $60^{\circ} \mathrm{C}$ 에서 농축하여 추출물 을 얻었다. 농축된 시료는 추출용매로 녹여 각각 $1.0,0.5$ 및 $0.25 \mathrm{mg} / \mathrm{mL}$ 농도로 제조하여 항산화 활성 및 효소저해활 성을 측정하였다.

\section{Phenolics 및 flavonoids 함량}

Phenolics 함량은 Folin-Denis법(16)을 약간 변형하여 측 정하였다. 추출물 $0.5 \mathrm{~mL}$ 를 시험관에 분주하고 $25 \%$ $\mathrm{Na}_{2} \mathrm{CO}_{3}$ 용액 $0.5 \mathrm{~mL}$ 를 첨가하여 3 분간 정치시켰다. 그 후 $2 \mathrm{~N}$ Folin-Ciocalteu phenol 용액 $0.25 \mathrm{~mL}$ 첨가 및 혼합한 다음 $30^{\circ} \mathrm{C}$ 에서 1 시간 동안 발색시켰다. 발색된 시료는 750 $\mathrm{nm}$ 에서 흡광도를 측정하였고, gallic acid를 이용하여 작성 한 표준 검량곡선으로부터 값을 산출하였다.

Flavonoids 함량은 Jia 등(17)의 방법에 따라 측정하였다. 추출물 $0.5 \mathrm{~mL}$ 를 대조구 및 시험용액으로 두 개의 시험관에 취하고 여기에 diethylene glycol $1.0 \mathrm{~mL}$ 및 $1 \mathrm{~N} \mathrm{NaOH} 0.01$ $\mathrm{mL}$ 를 가하여 $37^{\circ} \mathrm{C}$ 항온수조에서 1 시간 방치시켰다. 그 후 $420 \mathrm{~nm}$ 에서 흡광도를 측정하였고, rutin을 이용하여 작성한 표준 검량곡선으로부터 값을 산출하였다.

\section{항산화 활성}

$\mathrm{DPPH}$ 라디칼 소거능은 Hwang 등(18)의 방법에 따라 측정하였다. 즉 $\mathrm{DPPH}$ 용액 $0.8 \mathrm{~mL}$ 와 농도별 추출물 $(0.25$, 0.5 , 및 $1.0 \mathrm{mg} / \mathrm{mL}) 0.2 \mathrm{~mL}$ 를 가해 암실에서 30 분간 방치 후 $525 \mathrm{~nm}$ 에서 흡광도를 측정하였다.

$\mathrm{ABTS}$ 라디칼 소거능 역시 Hwang 등(18)의 방법과 동일 하게 측정하였다. $2.45 \mathrm{mM} \mathrm{K}_{2} \mathrm{~S}_{2} \mathrm{O}_{8} 5 \mathrm{~mL}^{2}$ 와 $7 \mathrm{mM} \mathrm{ABTS}^{\cdot+}$ $5 \mathrm{~mL}$ 를 혼합한 후 암실에서 12-16시간 반응시켜 ABTS 라디칼을 형성시킨 후 $732 \mathrm{~nm}$ 에서 대조구의 흡광도 값이 $0.7 \pm 0.02$ 가 되도록 조절한 $\mathrm{ABTS}$ 용액 $0.9 \mathrm{~mL}$ 와 농도별 추출물 $0.1 \mathrm{~mL}$ 를 첨가하여 3 분간 정치 시켜 $732 \mathrm{~nm}$ 에서 흡광도를 측정하였다.

Hydroxyl $(\mathrm{OH})$ 라디칼 소거능은 $10 \mathrm{mM} \mathrm{FeSO} \cdot \cdot 7 \mathrm{H}_{2} 0$ EDTA $0.2 \mathrm{~mL}, 10 \mathrm{mM}$ 2-deoxyribose $0.2 \mathrm{~mL}, 10 \mathrm{mM} \mathrm{H}_{2} \mathrm{O}_{2}$ $0.2 \mathrm{~mL}$, 및 농도별 추출물 $1.4 \mathrm{~mL}$ 를 혼합하고 $37^{\circ} \mathrm{C}$ 에서 4시간 동안 반응시켰다. 이 혼합액에 $1 \%$ thiobarbituric acid 와 $2.8 \%$ trichloroaceric acid를 각각 $1 \mathrm{~mL}$ 를 가하여 $100^{\circ} \mathrm{C}$ 에 서 20 분간 가열하여 발색 및 냉각시킨 후 $520 \mathrm{~nm}$ 에서 흡광 도를 측정하였다. 음성대조구 실험은 시료 대신에 PBS 완 충액 $\left(\mathrm{NaCl} 8.76 \mathrm{~g}, \mathrm{NaH}_{2} \mathrm{PO}_{4} 0.11 \mathrm{~g}, \mathrm{Na}_{2} \mathrm{HPO}_{4} 0.596 \mathrm{~g}\right)$ 을 사용하였고 라디칼 소거능은 시료용액의 첨가구와 무첨가 구 사이의 흡광도의 차이를 백분율(\%)로 나타내었다(19). 
탄수화물 및 지방 분해효소 저해활성 측정

a-Glucosidase 저해활성은 각 추출물 $50 \mu \mathrm{L}$, a-glucosidase $(0.5 \mathrm{U} / \mathrm{mL})$ 효소용액 $50 \mu \mathrm{L}, 200 \mathrm{mM}$ 인산나트륨 완충용액 (pH 6.8) $50 \mu \mathrm{L}$ 를 혼합하여 $37^{\circ} \mathrm{C}$ 에서 10 분간 예비반응 시켰 다. 이 후 인산나트륨 완충용액 $(\mathrm{pH} 6.8)$ 에 녹인 $\mathrm{p}-\mathrm{NPG}(5$ $\mathrm{mM}) 100 \mu \mathrm{L}$ 를 가하여 다시 $37^{\circ} \mathrm{C}$ 에서 10 분 반응시켰다. 이 반응액에 $\mathrm{Na}_{2} \mathrm{CO}_{3}(100 \mathrm{mM}) 0.75 \mathrm{~mL}$ 를 가해 최종 반응을 정지시킨 후 $420 \mathrm{~nm}$ 에서 분광광도계를 이용하여 흡광도를 측정하였다(2).

a-Amylase 저해활성은 각 추출물 $50 \mu \mathrm{L}$ 를 시험관에 분주 한 후 a-amylase $(1.0 \mathrm{U} / \mathrm{mL})$ 효소용액 $50 \mu \mathrm{L}$ 와 $200 \mathrm{mM}$ 인산 나트륨 완충용액 $(\mathrm{pH} 6.8) 50 \mu \mathrm{L}$ 를 첨가하여 $37^{\circ} \mathrm{C}$ 에서 10 분 간 예비 반응을 시켰다. 이 반응액에 $200 \mathrm{mM}$ 인산나트륨 완충용액 $(\mathrm{pH} 6.8)$ 에 녹인 $1 \%$ 전분용액을 $0.25 \mathrm{~mL}$ 를 가하여 다시 $37^{\circ} \mathrm{C}$ 에서 10 분간 반응 시켰다. 이후에는 $0.5 \mathrm{~N}-\mathrm{NaOH}$ 및 $30 \%$ 타르타르산나트륨칼륨을 용해한 $48 \mathrm{mM} \mathrm{DNS}$ 시약 을 $0.25 \mathrm{~mL}$ 첨가하여 $100^{\circ} \mathrm{C}$ 에서 20 분간 끓여 발색 및 냉각 시킨 후 $570 \mathrm{~nm}$ 에서 흡광도를 측정하였다 $(20,27)$.

Pancreatic lipase 저해활성은 Kwon 등(21)의 방법을 약간 변형하여 측정하였다. 추출물 $50 \mu \mathrm{L}$, lipase $(1.0 \mathrm{U} / \mathrm{mL})$ 효소 용액 $50 \mu \mathrm{L}$ 및 $100 \mathrm{mM}$ 인산나트륨 완충용액(pH 6.8) 50 $\mu \mathrm{L}$ 를 혼합하여 $37^{\circ} \mathrm{C}$ 에서 10 분간 예비 반응시켰다. 반응 후 인산나트륨 완충용액에 녹인 $p$ - NPB $(5 \mathrm{mM}) 100 \mu \mathrm{L}$ 를 가하여 동일하게 10 분간 반응시킨 후 $100 \mathrm{mM} \mathrm{Na}_{2} \mathrm{CO}_{3} 0.75$ $\mathrm{mL}$ 를 가해 반응을 종결시켜 $420 \mathrm{~nm}$ 에서 흡광도를 측정하 였다. 모든 효소 저해능의 음성대조구는 시료 대신에 추출 용매를 취하였으며 시료용액의 첨가구와 무첨가구 사이의 흡광도 차이를 백분율(\%)로 나타내었다.

\section{통계처리}

실험 결과는 SPSS 12.0 package를 사용하여 분산분석을 수행하였고 평균 \pm 표준편차로 나타내었다. 한편 각각의 분석 결과에 대환 유의성 검정은 분산분석 후 $\mathrm{p}<0.05$ 수준 에서 Ducan's multiple range test를 실시하였다.

\section{결과 및 고찰}

\section{영지버섯의 일반성분 함량}

원형영지버섯 및 녹각영지버섯의 일반성분을 분석한 결 과는 Table 1과 같았다. 탄수화물 함량은 원형이 $78.09 \%$ 와 녹각이 $61.20 \%$ 로 일반성분 중 대부분을 차지하였다. 수분 은 큰 차이 없이 평균 $10.1 \%$ 였으며 조지방 함량 역시 버섯 형태에 따른 큰 차이를 보이지는 않았다. 한편 조단백질의 경우에는 원형영지버섯은 $9.86 \%$ 였고, 녹각영지버섯은 $25.34 \%$ 로 원형보다는 2.3 배 이상 높았으며, 조회분은 원형 영지버섯이 $0.87 \%$ 를, 녹각영지버섯이 $1.33 \%$ 를 함유하고
있었다(Table 1).

Table 1. Comparison of proximate properties of two varieties of Genoderma lucidum

\begin{tabular}{ccc}
\hline \multirow{2}{*}{ Contents $(\mathrm{g} / 100 \mathrm{~g})$} & \multicolumn{2}{c}{ Type of fruiting body } \\
\cline { 2 - 3 } & Round & Nokgak \\
\hline Moisture & $10.09 \pm 0.50^{1 \mathrm{la} 2)}$ & $10.11 \pm 0.51^{\mathrm{b}}$ \\
Crude ash & $0.87 \pm 0.04^{\mathrm{b}}$ & $1.33 \pm 0.07^{\mathrm{a}}$ \\
Crude fat & $1.09 \pm 0.05^{\mathrm{b}}$ & $2.02 \pm 0.10^{\mathrm{a}}$ \\
Crude protein & $9.86 \pm 0.49^{\mathrm{b}}$ & $25.34 \pm 1.27^{\mathrm{a}}$ \\
Carbohydrate & $78.09 \pm 3.90^{\mathrm{a}}$ & $61.20 \pm 3.06^{\mathrm{b}}$ \\
\hline
\end{tabular}

\footnotetext{
${ }^{1)}$ All values are presented as the mean $\pm \mathrm{SD}$ of triplicate determination.

${ }^{2)}$ All values within a column with different superscript letters are significantly different from each other at $\mathrm{p}<0.05$ by Duncan's multiple range test.
}

Lee 등(21)은 영지버섯의 일반성분 중 탄수화물은 평균 $79 \%$, 조단백질은 평균 $13 \%$, 조지방은 평균 $3.7 \%$ 및 조회분 은 약 평균 $1.3 \%$ 로 탄수화물과 조단백질은 원형영지버섯이 많았고 조지방과 조회분은 녹각영지버섯이 많다고 보고하 여 본 연구와 약간 다른 함량을 나타내었다. 이는 영지버섯 품종의 차이뿐만 아니라 재배방식, 재배기간 등의 환경적 요인 차이, 버섯 수확 후 저장과 건조 방법, 추출 방법의 다양성에 의한 것으로 판단되었다.

영지버섯의 아미노산 및 지방산 함량

원형 및 녹각 영지버섯의 아미노산을 분석한 결과는 Table 2에 나타낸바와 같이 비필수 아미노산(aspartic acid, serine, glutamic acid, proline, glycine, alanine, 및 arginine) 7 종과 필수 아미노산(threonine, valine, isoleucine, leucine, phenylalanine, lysine, 및 histidine) 7 종이 검출되어 총 14 종류의 아미노산이 검출되었다. 아미노산 총 함량은 원형 영지버섯이 $43.40 \mathrm{mg} / \mathrm{g}$ 이었고 녹각 영지버섯이 $63.84 \mathrm{mg} / \mathrm{g}$ 으로 조단백질 함량과 동일하게 녹각 영지버섯이 높았다. 한편 비필수 아미노산의 경우 원형 영지버섯은 aspartic acid 와 glutamic acid가 각각 $3.47 \mathrm{mg} / \mathrm{g}$ 및 $3.64 \mathrm{mg} / \mathrm{g}$ 이었고, 녹각 영지버섯은 각각 $5.63 \mathrm{mg} / \mathrm{g}$ 와 $5.54 \mathrm{mg} / \mathrm{g}$ 을 함유하고 있었으며 필수 아미노산인 valine은 원형 영지버섯과 녹각 영지버섯에서 각각 $11.90 \mathrm{mg} / \mathrm{g}$ 과 $17.18 \mathrm{mg} / \mathrm{g}$ 으로 영지버섯 의 주요 아미노산이었다.

Cho 등(12)은 영지버섯 종류에 따라 함유된 아미노산을 조사한 결과 검출된 아미노산 종류는 본 연구와 동일한 결과로 나타냈었으나, 각각의 아미노산 함량에는 약간씩 차이가 있음을 보고하였다. Lee 등(22)은 영지버섯 종류와 산지별 아미노산 분석 결과 녹각 영지버섯은 12 종, 국산 재배 또는 야생 원형 영지버섯은 각각 15 종, 대만에서 재배 된 원형영지버섯은 16 종이 검출되었음을 보고하였다. 한 편 Lee 등(21)은 원형 및 녹각에서 모두 leucine이 가장 많았 
고 methionine이 가장 적음을 보고하여 본 연구결과와는 상이하였다. 이는 영지버섯의 품종뿐만 아니라 재배법, 재 배기간 등의 환경적 요인 차이에 따른 것으로 판단되었다.

Table 2. Comparison of amino acid compositions of two varieties of Genoderma lucidum

\begin{tabular}{ccc}
\hline \multirow{3}{*}{ Amino acids (mg/g) } & \multicolumn{2}{c}{ Type of fruiting body } \\
\cline { 2 - 3 } Round & Nokgak \\
\hline Aspartic acid & $3.47 \pm 0.44^{11 \mathrm{b2})}$ & $5.54 \pm 0.60^{\mathrm{a}}$ \\
Serine & $2.30 \pm 0.36^{\mathrm{b}}$ & $3.15 \pm 0.42^{\mathrm{a}}$ \\
Glutamic acid & $3.64 \pm 0.40^{\mathrm{b}}$ & $5.63 \pm 0.65^{\mathrm{a}}$ \\
Proline & $1.85 \pm 0.11^{\mathrm{b}}$ & $2.56 \pm 0.19^{\mathrm{a}}$ \\
Glycine & $2.21 \pm 0.38^{\mathrm{b}}$ & $3.11 \pm 0.26^{\mathrm{a}}$ \\
Alanine & $2.60 \pm 0.32^{\mathrm{b}}$ & $3.89 \pm 0.39^{\mathrm{a}}$ \\
Cystine & $\mathrm{ND}$ & $\mathrm{ND}$ \\
Tyrosine & $\mathrm{ND}$ & $\mathrm{ND}$ \\
Arginine & $1.63 \pm 0.19^{\mathrm{b}}$ & $2.65 \pm 0.46^{\mathrm{a}}$ \\
Total & $17.70 \pm 0.89^{\mathrm{b}}$ & $26.53 \pm 1.33^{\mathrm{a}}$ \\
\hline & Essential amino acids \\
Threonine & $2.45 \pm 0.35^{\mathrm{b}}$ & $3.61 \pm 0.45^{\mathrm{a}}$ \\
Valine & $11.90 \pm 0.38^{\mathrm{b}}$ & $17.18 \pm 1.36^{\mathrm{a}}$ \\
Isoleucine & $2.77 \pm 0.31^{\mathrm{b}}$ & $4.62 \pm 0.92^{\mathrm{a}}$ \\
Leucine & $2.84 \pm 0.16^{\mathrm{b}}$ & $4.14 \pm 0.44^{\mathrm{a}}$ \\
Phenylalanine & $2.32 \pm 0.37^{\mathrm{b}}$ & $3.16 \pm 0.23^{\mathrm{a}}$ \\
Lysine & $2.51 \pm 0.27^{\mathrm{b}}$ & $3.28 \pm 0.33^{\mathrm{a}}$ \\
Histidine & $0.91 \pm 0.10^{\mathrm{b}}$ & $1.32 \pm 0.21^{\mathrm{a}}$ \\
Methionine & $\mathrm{ND}$ & $\mathrm{ND}$ \\
Total & $25.70 \pm 1.29^{\mathrm{b}}$ & $37.31 \pm 1.87^{\mathrm{a}}$ \\
\hline
\end{tabular}

${ }^{1)}$ All values are presented as the mean $\mathrm{SD}$ of triplicate determination.

${ }^{2}$ All values within a column with different superscript letters are significantly different from each other at $\mathrm{p}<0.05$ by Duncan's multiple range test.

${ }^{3} \mathrm{ND}$, not detected.

원형 및 녹각 영지버섯의 지방산을 분석한 결과는 Table 3 과 같았다. 지방산은 포화지방산에 속하는 myristic $\operatorname{acid}(\mathrm{C} 14: 0)$, plamitic $\operatorname{acid}(\mathrm{C} 16: 0)$, behenic $\operatorname{acid}(\mathrm{C} 22: 0)$, tricosylic $\operatorname{acid}(\mathrm{C} 23: 0)$ 및 lignoceric $\operatorname{acid}(\mathrm{C} 24: 0) 5$ 종과 불포 화지방산에 속하는 cis-vaccenic $\operatorname{acid}(\mathrm{C} 18: \ln 7)$, oleic acid (C18:1n9), lineolic acid(C18:2n6) 및 a-linolenic acid(C18:3n3) 는 4종이 검출되었고 지방산의 분포도 비율은 두 버섯 모두 유사하였다. 원형 영지버섯의 주요 지방산은 불포화지방산 인 linoleic acid(47.56\%)와 oleic acid(32.91\%)로 나타났고 녹각 영지버섯은 linoleic acid가 $75.68 \%$ 로 지방산의 대부분 을 차지하였으며 원형 및 녹각영지버섯 모두 불포화지방산 이 약 $80 \%$ 이상을 차지하였다.

이전의 보고에 따르면 영지버섯의 지방산은 포화지방산
보다는 불포화지방산(linoleic acid) 함량이 높은 것으로 보 고하였으며 원형 영지버섯의 경우linoleic acid와 oleic acid 가 각각 $45.7 \%$ 와 $34.4 \%$ 로 본 연구와 유사한 비율 있었으나, 녹각 영지버섯의 경우 linoleic acid와 oleic acid가 각각 $45.3 \%$ 와 $34.1 \%$ 로 본 연구와는 상이한 결과를 보였다(21). 특히 동일한 품종인 녹각 영지버섯에서 지방산 조성 비율이 다른 이유는 재배방식, 재배기간 등의 재배법 즉 환경적 요인의 차이에 의한 것으로 추정되었다.

Table 3. Comparison of fatty acid compositions of two varieties of Genoderma lucidum

\begin{tabular}{ccc}
\hline \multirow{2}{*}{ Fatty acids (\% weight) } & \multicolumn{2}{c}{ Type of fruiting body } \\
\cline { 2 - 3 } & Round & Nokgak \\
\hline Saturated fatty acids & & \\
Myristic (C14:0) & $1.61 \pm 0.08^{1 \mathrm{~b} 2)}$ & $3.35 \pm 0.17^{\mathrm{a}}$ \\
Palmitic (C16:0) & $13.50 \pm 0.68^{\mathrm{a}}$ & $9.44 \pm 0.47^{\mathrm{b}}$ \\
Behenic (C22:0) & $0.35 \pm 0.02^{\mathrm{a}}$ & $0.36 \pm 0.02^{\mathrm{a}}$ \\
Tricosylic (C23:0) & $0.37 \pm 0.02^{\mathrm{b}}$ & $0.70 \pm 0.04^{\mathrm{a}}$ \\
Lignoceric (C24:0) & $0.54 \pm 0.03^{\mathrm{a}}$ & $0.43 \pm 0.02^{\mathrm{a}}$ \\
Total & $16.37 \pm 0.98^{\mathrm{a}}$ & $14.28 \pm 1.02^{\mathrm{b}}$ \\
\hline Unsaturated fatty acids & & \\
cis-Vaccenic (C18:1n7) & $2.95 \pm 0.15^{\mathrm{b}}$ & $3.55 \pm 0.18^{\mathrm{a}}$ \\
Oleic (C18:1n9) & $32.91 \pm 1.65^{\mathrm{a}}$ & $6.21 \pm 0.31^{\mathrm{b}}$ \\
Linoleic (C18:2n6) & $47.56 \pm 2.38^{\mathrm{b}}$ & $75.68 \pm 3.78^{\mathrm{a}}$ \\
a-Linolenic (C18:3n3) & $0.21 \pm 0.01^{\mathrm{a}}$ & $0.28 \pm 0.01^{\mathrm{a}}$ \\
Total & $83.63 \pm 5.22^{\mathrm{b}}$ & $85.72 \pm 5.16^{\mathrm{a}}$ \\
\hline
\end{tabular}

\footnotetext{
${ }^{1)}$ All values are presented as the mean \pm SD of triplicate determination.

${ }^{2)}$ All values within a column with different superscript letters are significantly different from each other at $\mathrm{p}<0.05$ by Duncan's multiple range test.
}

\section{영지버섯의 무기질 함량}

원형 및 녹각 영지버섯의 무기질 함량을 분석한 결과는 Table 4와 같았다. 원형 영지버섯의 주요 무기질은 칼숨 $(137.17 \mathrm{mg} / \mathrm{g})$ 및 칼륨 $(116.50 \mathrm{mg} / \mathrm{g})$ 이었다. 녹각 영지버섯 의 주요 무기질은 칼륨 $(184.36 \mathrm{mg} / \mathrm{g})$ 및 인 $(170.90 \mathrm{mg} / \mathrm{g})$ 으 로 원형 영지버섯과는 무기질 분포도의 차이가 있었다. 한 편 철 함량은 원형 $(0.91 \mathrm{mg} / \mathrm{g})$ 및 녹각 $(1.37 \mathrm{mg} / \mathrm{g})$ 두 버섯 간에 큰 차이는 없었고 나트륨은 녹각 영지버섯이 64.15 $\mathrm{mg} / \mathrm{g}$ 으로 약 4배 이상 높게 함유하고 있었다. 이 외 마그네 슘의 경우 원형 영지버섯이 $28.42 \mathrm{mg} / \mathrm{g}$ 을, 녹각 영지버섯이 $47.44 \mathrm{mg} / \mathrm{g}$ 을 함유하고 있었다. 또한 이들의 총 함량은 $388.94 \mathrm{mg} / \mathrm{g}$ (원형) 및 $492.49 \mathrm{mg} / \mathrm{g}$ (녹각)으로 전체적으로 녹각 영지버섯이 많은 양의 무기질을 함유하고 있는 것으로 나타났다.

Lee 등(21)은 영지버섯의 무기질을 분석한 결과 녹각 영 지버섯이 원형 영지버섯보다는 무기질 함량이 높다고 하여 본 연구결과 유사하였으나, 칼륨 > 인 > 마그네슘 > 칼슘 
> 소금 순으로 많이 함유되어 있다고 보고하여 본 연구결과 와는 다른 결과를 나타내었다. 무기질은 인체에 약 $4 \%$ 가량 축적되어 있으나 체내에서 합성되지 않아 필히 식품으로 섭취해야만 한다(23). 이 중 철은 활성산소 제거에 관여를 하고(23), 인의 경우 세포 노화 억제에 큰 영향을 미친다고 보고되어 있다(24). 본 연구에서도 녹각 영지버섯의 인 함량 이 $170.90 \mathrm{mg} / 100 \mathrm{~g}$ 으로 가장 높았고 원형 영지버섯도 비교 적 높은 함유량을 나타내 이들의 잠재적 기능성이 있을 것이라 판단된다. 따라서 인체에 필요한 각종 무기질을 함 유한 영지버섯은 무기질 급원에 우수한 식품으로 사료된 다.

Table 4. Comparison of mineral compositions of two varieties of Genoderma lucidum

\begin{tabular}{ccc}
\hline \multirow{2}{*}{ Contents (mg/100 g) } & \multicolumn{2}{c}{ Type of fruiting body } \\
\cline { 2 - 3 } & Round & Nokgak \\
\hline Iron & $0.91 \pm 0.05^{1 \mathrm{~b} 2)}$ & $1.37 \pm 0.07^{\mathrm{a}}$ \\
Sodium & $14.52 \pm 0.73^{\mathrm{b}}$ & $64.15 \pm 3.21^{\mathrm{a}}$ \\
Calcium & $137.73 \pm 6.89^{\mathrm{a}}$ & $24.27 \pm 1.21^{\mathrm{b}}$ \\
Potassium & $116.50 \pm 5.83^{\mathrm{b}}$ & $184.36 \pm 9.22^{\mathrm{a}}$ \\
Magnesium & $28.42 \pm 1.42^{\mathrm{b}}$ & $47.44 \pm 2.37^{\mathrm{a}}$ \\
Phosphorus & $90.86 \pm 4.54^{\mathrm{b}}$ & $170.90 \pm 8.55^{\mathrm{a}}$ \\
Total & $388.94 \pm 19.45^{\mathrm{b}}$ & $492.49 \pm 24.62^{\mathrm{a}}$ \\
\hline
\end{tabular}

${ }^{1)}$ All values are presented as the mean $\pm \mathrm{SD}$ of triplicate determination.

${ }^{2}$ All values within a column with different superscript letters are significantly different from each other at $\mathrm{p}<0.05$ by Duncan's multiple range test.

\section{영지버섯의 $\beta$-glucan 및 수용성 비타민 함량}

원형 및 녹각 영지버섯의 $\beta$-glucan 및 수용성 비타민 함량 을 분석한 결과는 Table 5 와 같았다. $\beta$-Glucan 함량은 원형 영지버섯이 $34.15 \mathrm{~g} / 100 \mathrm{~g}$ 이었고 녹각 영지버섯은 30.07 $\mathrm{g} / 100 \mathrm{~g}$ 으로 비슷한 수준이었다. 비타민 $\mathrm{B}_{3}$ 는 원형 영지버 섯이 $1.78 \mathrm{mg} / 100 \mathrm{~g}$, 녹각 영지버섯이 $1.81 \mathrm{mg} / 100 \mathrm{~g}$ 으로 수용성 비타민 중 $65.7 \%$ 와 $56.9 \%$ 를 차지하였고 그 다음으 로 비타민 $\mathrm{B}_{2}$ 가 각각 $0.70 \mathrm{mg} / 100 \mathrm{~g}$ 및 $1.11 \mathrm{mg} / 100 \mathrm{~g}$, 비타민 $\mathrm{B}_{1}$ 이 각각 $0.23 \mathrm{mg} / 100 \mathrm{~g}$ 및 $0.26 \mathrm{mg} / 100 \mathrm{~g}$ 으로 나타났다.

Cho 등(15)은 영지버섯 균주별 $\beta$-glucan 함량을 분석한 결과 약 $15-20 \%$ 수준으로 보고하여 본 연구 결과보다는 낮게 나타났다. $\beta$-Glucan은 버섯의 대표적인 생리활성 물질 로 항암작용 및 혈압강하작용 등 여러 생리활성을 지니고 있다(25). 한편 비타민류는 소나무 잔나비버섯의 경우 비타 민 $\mathrm{B}_{1}$ 은 $0.11 \mathrm{mg} / 100 \mathrm{~g}$ 이었고 비타민 $\mathrm{B}_{2}$ 는 $0.30 \mathrm{mg} / 100$ $\mathrm{g}$ 이 검출되었으며(26) 차신버섯은 비타민 $\mathrm{B}_{1}$ 의 경우 1.29 $\mathrm{mg} / 100 \mathrm{~g}$, 비타민 $\mathrm{B}_{2}$ 는 $0.15 \mathrm{mg} / 100 \mathrm{~g}$ 및 비타민 $\mathrm{B}_{3}$ 는 0.32 $\mathrm{mg} / 100 \mathrm{~g}$ 으로 보고하여(23) 약간 높거나 유사한 함량을 나타내었다. 이러한 차이는 버섯의 종류와 재배 방법 등의 환경적 요인이 가장 크게 영향을 받는 것이라 판단된다.
더욱이 비타민 $\mathrm{B}_{1}$ 은 pyruvate dehydrogenase에 관여하여 에 너지 대사에 참여하는 비타민으로 알려져 있으며(23), 최근 항균 효능(27)이 있는 것으로 보고되어 식품뿐만 아니라 화장품 산업 등 다방면에서 활용되므로 기능성 소재로 잠재 적 가치가 클 것으로 예상된다.

Table 5. Comparison of $\beta$-glucan and vitamin compositions of two varieties of Genoderma lucidum

\begin{tabular}{ccc}
\hline \multirow{2}{*}{ Contents } & \multicolumn{2}{c}{ Type of fruiting body } \\
\cline { 2 - 3 } & Round & Nokgak \\
\hline B-Glucan $(\mathrm{g} / 100 \mathrm{~g})$ & $34.15 \pm 5.45^{1) 22}$ & $30.07 \pm 5.03^{\mathrm{b}}$ \\
\hline Soluble vitamin $(\mathrm{mg} / 100 \mathrm{~g})$ & & \\
Vitamin $\mathrm{B}_{1}$ & $0.23 \pm 0.01^{\mathrm{a}}$ & $0.26 \pm 0.01^{\mathrm{a}}$ \\
Vitamin $\mathrm{B}_{2}$ & $0.70 \pm 0.04^{\mathrm{b}}$ & $1.11 \pm 0.06^{\mathrm{a}}$ \\
Vitamin $\mathrm{B}_{3}$ & $1.78 \pm 0.09^{\mathrm{a}}$ & $1.81 \pm 0.09^{\mathrm{a}}$ \\
Total & $2.71 \pm 0.11^{\mathrm{b}}$ & $3.18 \pm 0.15^{\mathrm{a}}$ \\
\hline
\end{tabular}

\footnotetext{
${ }^{1)}$ All values are presented as the mean \pm SD of triplicate determination.

${ }^{2)}$ All values within a column with different superscript letters are significantly different from each other at $p<0.05$ by Duncan's multiple range test.
}

영지버섯 추출물의 phenolics 및 flavonoids 함량 원형 및 녹각 영지버섯의 에탄올 추출조건별 phenolics 및 flavonoids 함량은 결과적으로 $40^{\circ} \mathrm{C}$ 에서 추출하였을 시 $70^{\circ} \mathrm{C}$ 에서보다 phenolics 및 flavonoids 함량이 약간 높았으 나 큰 차이는 없었으며 $70 \%$ 에탄올 추출조건에서 높은 함량을 나타내었다(Table 6). Phenolics 함량은 원형 영지버 섯이 녹각 영지버섯보다 월등히 높은 함량을 나타내었다. 원형 영지버섯의 경우 $40^{\circ} \mathrm{C}-70 \%$ 에탄올 추출물이 10.44 $\mathrm{mg} / \mathrm{g}$ 으로 추출물 중 가장 높은 함량을 보였고, $70^{\circ} \mathrm{C}-70 \%$ 에탄올 추출물은 $9.09 \mathrm{mg} / \mathrm{g}$ 을 나타내었다. 한편 녹각 영지 버섯은 원형 영지버섯보다 약 10 배 낮은 함량으로 $40^{\circ} \mathrm{C}$ $-70 \%$ 에탄올 추출물이 $1.43 \mathrm{mg} / \mathrm{g}, 70^{\circ} \mathrm{C}-70 \%$ 에탄올 추출물 이 $1.27 \mathrm{mg} / \mathrm{g}$ 을 함유하고 있었다(Table 6).

Flavonoids 함량은 총 phenolics 함량과는 달리 원형 영지 버섯과 녹각 영지버섯 모두 유사한 함량을 보였다. 원형 및 녹각영지버섯의 $40^{\circ} \mathrm{C}-70 \%$ 에탄올 추출물에서 각각 0.32 $\mathrm{mg} / \mathrm{g}$ 을 나타내었고 $70^{\circ} \mathrm{C}-70 \%$ 에탄올 추출물에서 각각 0.27 $\mathrm{mg} / \mathrm{g}$ 과 $0.21 \mathrm{mg} / \mathrm{g}$ 으로 커다란 차이를 보이지 않았다(Table 6).

식물성 ployphenol성 화합물은 대표적인 항산화 물질로 hydroxyl기를 통해 활성산소를 안정적으로 제거하는 물질 이다(25). 최근 결과에 따르면 추출용매에 따라 용출되는 ployphenol성 화합물 양상이 다르며 일반적으로 ployphenol 성 화합물 함량과 항산화 활성과의 상관관계가 크다는 연구 가 보고되었다(2). Choi 등(1)도 식용버섯인 상황버섯(17.23 $\mathrm{mg} / \mathrm{g})$, 양송이버섯 $(9.45 \mathrm{mg} / \mathrm{g})$ 및 송이버섯 $(5.72 \mathrm{mg} / \mathrm{g})$ 이 많은 양의 polyphenol성 화합물을 함유하고 있음을 보고하 였으며, 물 추출물보다는 에탄올 추출물에서 용출되는 생 
리활성 물질이 많다고 보고하였고 이는 본 연구 결과와도 유사하였다.

Table 6. Comparison of total phenolic and total flavonoid contents of two varieties of Genoderma lucidum depending on the different concentrations of ethanol extraction

\begin{tabular}{|c|c|c|c|c|}
\hline \multirow{3}{*}{$\begin{array}{l}\text { Different extraction } \\
\text { system using ethanol }\end{array}$} & \multicolumn{4}{|c|}{ Type of fruiting body } \\
\hline & \multicolumn{2}{|c|}{ Round } & \multicolumn{2}{|c|}{ Nokgak } \\
\hline & Temp. $40^{\circ} \mathrm{C}$ & Temp. $70^{\circ} \mathrm{C}$ & Temp. $40^{\circ} \mathrm{C}$ & Temp. $70^{\circ} \mathrm{C}$ \\
\hline \multicolumn{5}{|c|}{ Total phenolics contents $(\mathrm{mg} / \mathrm{g})$} \\
\hline $30 \%$ & $5.86 \pm 0.29^{1) \mathrm{a}(2)}$ & $4.81 \pm 0.24^{\mathrm{bC}}$ & $1.29 \pm 0.06^{\mathrm{CB}}$ & $1.10 \pm 0.06^{\mathrm{cA}}$ \\
\hline $50 \%$ & $7.36 \pm 0.37^{\mathrm{aB}}$ & $7.21 \pm 0.36^{\mathrm{aB}}$ & $1.37 \pm 0.07^{\mathrm{bAB}}$ & $1.22 \pm 0.06^{\mathrm{bA}}$ \\
\hline $70 \%$ & $10.44 \pm 0.52^{\mathrm{aA}}$ & $9.09 \pm 0.45^{\mathrm{bA}}$ & $1.43 \pm 0.07^{\mathrm{cA}}$ & $1.27 \pm 0.06^{\mathrm{cA}}$ \\
\hline $95 \%$ & $8.55 \pm 0.43^{a B}$ & $7.93 \pm 0.40^{\mathrm{aB}}$ & $0.96 \pm 0.05^{\mathrm{bC}}$ & $0.72 \pm 0.04^{b B}$ \\
\hline \multicolumn{5}{|c|}{ Total flavonoids contents (mg/g) } \\
\hline $30 \%$ & $0.17 \pm 0.01^{\mathrm{aC}}$ & $0.14 \pm 0.01^{\mathrm{aB}}$ & $0.18 \pm 0.01^{\mathrm{aC}}$ & $0.10 \pm 0.01^{\mathrm{aC}}$ \\
\hline $50 \%$ & $0.23 \pm 0.01^{\mathrm{aB}}$ & $0.21 \pm 0.01^{\mathrm{aA}}$ & $0.26 \pm 0.02^{\mathrm{aB}}$ & $0.15 \pm 0.01^{\mathrm{aB}}$ \\
\hline $70 \%$ & $0.32 \pm 0.02^{\mathrm{aA}}$ & $0.27 \pm 0.02^{\mathrm{aA}}$ & $0.32 \pm 0.02^{\mathrm{aA}}$ & $0.21 \pm 0.02^{\mathrm{aA}}$ \\
\hline $95 \%$ & $0.25 \pm 0.02^{\mathrm{aB}}$ & $0.23 \pm 0.01^{\mathrm{aA}}$ & $0.24 \pm 0.01^{\mathrm{aBC}}$ & $0.16 \pm 0.01^{\mathrm{aB}}$ \\
\hline
\end{tabular}

${ }^{1)}$ All values are presented as the mean $\pm \mathrm{SD}$ of triplicate determination.

${ }^{2)}$ All values within a column with different superscript letters of different extraction systems (EtOH concretions and temperatures) with significantly different from each other at $\mathrm{p}<0.05$ by Duncan's multiple range test.

\section{영지버섯 추출물의 항산화 활성}

원형 및 녹각 영지버섯의 에탄올 추출조건별 $\mathrm{DPPH}$, ABTS 및 hydroxyl 라디칼 소거능을 측정한 결과는 Fig. $1-3$ 과 같았다. 모든 라디칼 소거능은 $40^{\circ} \mathrm{C}$ 에서 추출한 경우 $70^{\circ} \mathrm{C}$ 보다 높았으나 커다란 차이를 보이지는 않았고, 원형 영지버섯이 녹각 영지버섯보다는 라디칼 소거능이 우수하 였다.

$\mathrm{DPPH}$ 라디칼 소거능은 $40^{\circ} \mathrm{C}-70 \%$ 원형 영지버섯 추출물 $(0.25 \mathrm{mg} / \mathrm{mL})$ 에서는 $91.51 \%$ 를, $70^{\circ} \mathrm{C}-70 \%$ 추출물에서는 $85.38 \%$ 를 나타내었고(Fig. $1 \mathrm{~A}) 40^{\circ} \mathrm{C}-70 \%$ 녹각 영지버섯 추출물 $(0.25 \mathrm{mg} / \mathrm{mL})$ 에서는 $66.74 \%$ 를, $70^{\circ} \mathrm{C}-70 \%$ 추출물에 서는 $45.74 \%$ 를 나타내었다(Fig. 1B).

$\mathrm{ABTS}$ 라디칼 소거능은 $\mathrm{DPPH}$ 와는 다르게 추출물의 처 리 농도에 따른 차이를 보이지 않았다. Fig. 2A에 나타낸 바와 같이 $40^{\circ} \mathrm{C}$ 에서 $70 \%$ 에탄올로 추출한 경우 원형 영지 버섯 추출물 $(0.25 \mathrm{mg} / \mathrm{mL})$ 은 $99.51 \%$ 를 나타내었고 $70^{\circ} \mathrm{C}$ 에 서 $70 \%$ 에탄올 추출물 $(0.25 \mathrm{mg} / \mathrm{mL})$ 에서는 $97.26 \%$ 의 아주 우수한 라디칼 소거능을 나타내었다. $40^{\circ} \mathrm{C}$ 에서 $70 \%$ 에탄올 로 추출한 녹각 영지버섯 $(0.25 \mathrm{mg} / \mathrm{mL})$ 추출물 역시 $97.23 \%$ 를 나타내었고 $70^{\circ} \mathrm{C}$ 에서 $70 \%$ 에탄올로 추출한 경우도 마찬 가지로 $96.08 \%$ 의 높은 소거능을 나타내었다.

Hydroxyl 라디칼 소거능은 DPPH 라디칼 소거능과 동일 하게 추출물의 농도가 증가할수록 소거능 역시 증가하였 다. 원형 영지버섯은 추출온도에 따라 거의 차이가 없었으
며, 녹각 영지버섯은 $40^{\circ} \mathrm{C}$ 가 $70^{\circ} \mathrm{C}$ 보다는 약간 높은 소거능 을 보였다. $40^{\circ} \mathrm{C}$ 에서 $70 \%$ 에탄올로 추출한 원형 영지버섯 추출물 $(1.0 \mathrm{mg} / \mathrm{g})$ 에서는 $61.64 \%$ 를 나타내었고 $70^{\circ} \mathrm{C}$ 에서 $70 \%$ 에탄올로 추출한 경우에는 $58.09 \%$ 의 소거능을 나타내 었다(Fig. 3A). 한편 녹각 영지버섯 추출물의 경우에는 $\mathrm{DPPH}$ 와 $\mathrm{ABTS}$ 라디칼 소거능과 달리 $40^{\circ} \mathrm{C}$ 에서 $95 \%$ 에탄 올로 추출한 경우 라디칼 소거능이 가장 높았으나 $40^{\circ} \mathrm{C}$ 에서 $70 \%$ 에탄올로 추출한 경우와 큰 차이를 나타내진 않았다 (Fig. 3B).

이와 같은 우수한 라디칼 소거능은 $\mathrm{Oh}$ 등(28)이 이전에 보고한 것처럼 버섯 자실체에 존재하는 polyphenol성 화합 물에 기인한 것으로 판단되었고 Hur 등(29)과 Cha 등(30) 역시 유사한 결과를 보고하였다. 일반적으로 $\mathrm{ABTS}$ 와 $\mathrm{DPPH}$ 는 라디칼이지만 자유 라디칼(DPPH)과 양이온 라디 칼(ABTS)이라는 점에서 $\mathrm{ABTS}$ 가 $\mathrm{DPPH}$ 보다 더 높은 항산 화력을 나타내는 지표로 사용이 된다(31). 본 연구 역시 저 농도 처리 시 DPPH 라디칼 소거능보다 ABTS 라디칼 소거능이 우수하여 Cha 등(31)의 결과와 일치하였다. 한편 Cheung 등(32)과 Choi 등(1)의 보고에 따르면 polyphenol성
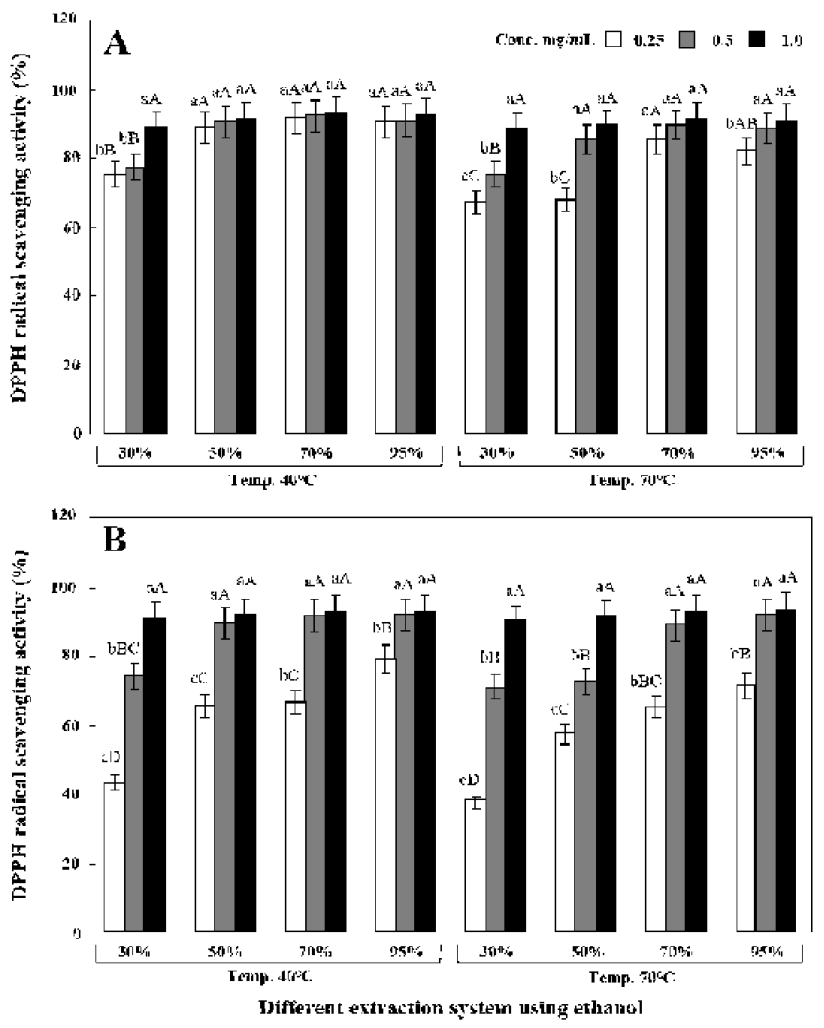

Fig. 1. Comparison of DPPH radical scavenging activity of two varieties of Genoderma lucidum depending on the different concentrations of ethanol extraction.

A, Round type of fruiting body; B, Nokgak type of fruiting body.

All values are presented as the mean \pm SD of triplicate determination. All values within a column with different supesscript letters of different extraction systems (EtOH concretions and temperatures) with significantly different from each other at $p<0.05$ by Duncan's multiple range test. 

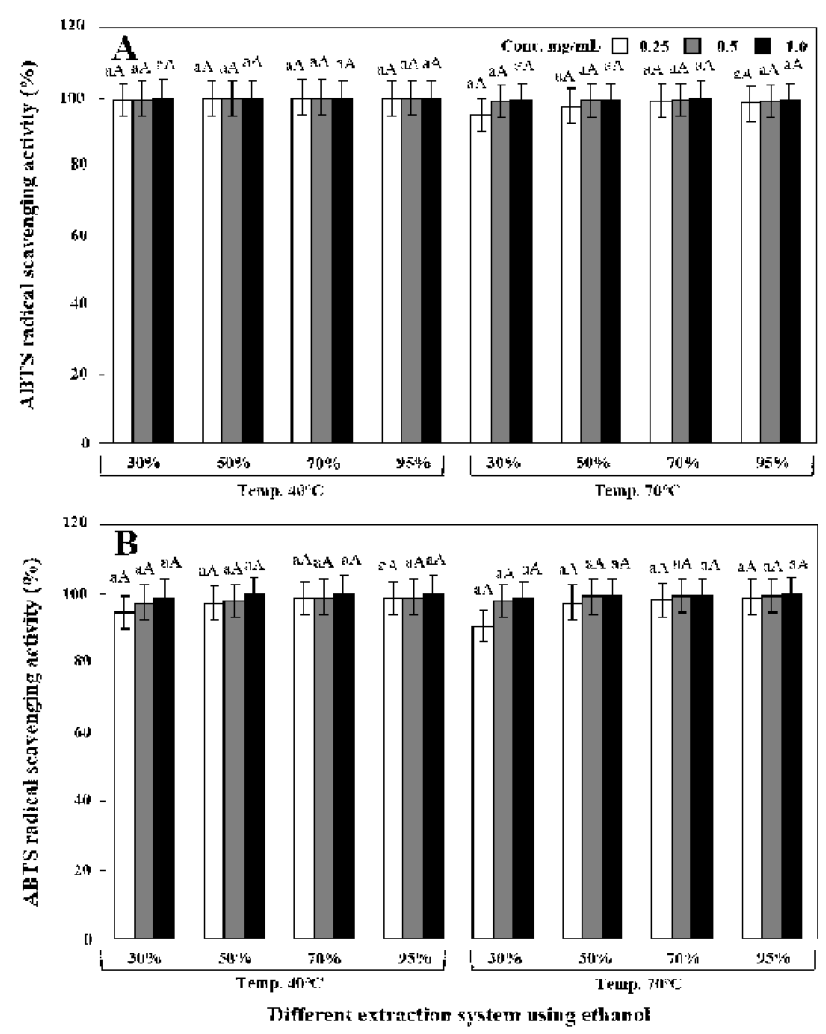

Fig. 2. Comparison of ABTS radical scavenging activity of two varieties of Genoderma lucidum depending on the different concentrations of ethanol extraction.

A, Round type of fruiting body; B, Nokgak type of fruiting body. All values are presented as the mean $\pm S D$ of triplicate determination. All values within a column with different superscript letters of different extraction systems (EtOH concretions and temperatures) with significantly different from each other at $p<0.05$ by Duncan's multiple range test.

화합물과 라디칼 소거능은 정의 상관관계에 있다고 보고하 여 본 연구결과와 유사하였다. 부가적으로 hydroxyl 라디칼 $(\mathrm{OH})$ 은 세포막의 탄수화물, 단백질, 지질 및 DNA를 포함한 대부분의 생체 분자와 아주 쉽게 반응할 수 있으며 이로 인해 세포조직의 손상 또는 사멸을 일으키는 원인이 된다 (33). 이러한 라디칼 연쇄반응에 $\mathrm{H}$ 를 공급함으로써 종결시 키는데 관여하는 가장 주된 물질은 $\beta$-glucan인 것으로 보고 되어 있다(33). 따라서 본 연구에서는 $\beta$-glucan뿐만 아니라 phenolics 및 flaovonoids에 의한 것으로 추정되었다.

\section{영지버섯 추출물의 효소저해활성}

원형 및 녹각 영지버섯의 에탄올 추출조건별 a-glucosidase 및 a-amylase 저해활성 결과는 Fig. 4-5에 나타내었다.

a-Glucosidase 저해활성은 전체적으로 $40^{\circ} \mathrm{C}$ 에서 추출한 경우 $70^{\circ} \mathrm{C}$ 보다 효소 저해활성이 좀 더 우수하였다. $40^{\circ} \mathrm{C}$ 에 서 $70 \%$ 에탄올로 추출한 원형영지버섯 추출물 $(0.5 \mathrm{mg} / \mathrm{mL})$ 에서는 a-glucosidase 저해활성이 $80.66 \%$ 를 나타내었고 7 $0^{\circ} \mathrm{C}$ 에서는 $67.79 \%$ 를 나타내었다(Fig. 4A). 한편 녹각 영지 버섯 추출물 $(0.5 \mathrm{mg} / \mathrm{mL})$ 은 $40^{\circ} \mathrm{C}$ 에서 $95 \%$ 에탄올로 추출하
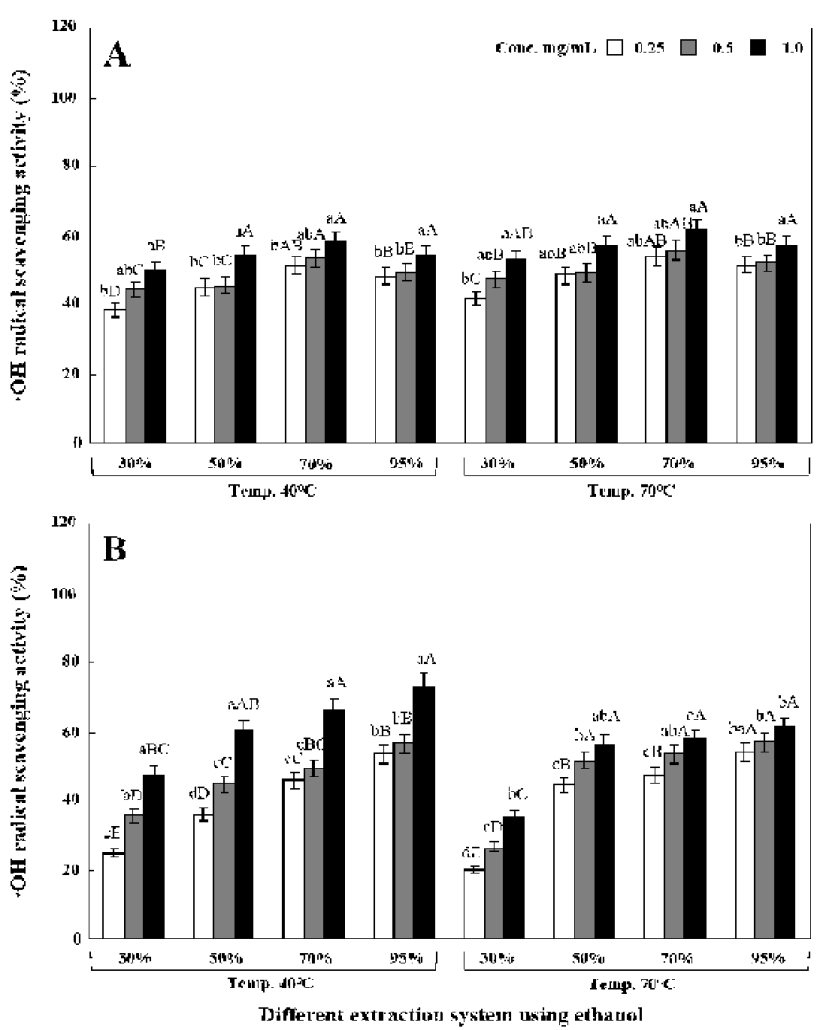

Fig. 3. Comparison of hydroxyl radical scavenging activity on extracted Genoderma lucidum of fruiting bodies from different extract system of ethanol.

A, Round type of fruiting body; B, Nokgak type of fruiting body.

All values are presented as the mean \pm SD of triplicate determination. All values within a column with different superscript letters of different extraction systems (EtOH concretions and temperatures) with significantly different from each other at $\mathrm{p}<0.05$ by Duncan's multiple range test.

였을 시 a-glucosidase 저해활성이 가장 우수하였고 $70 \%$ 에탄올 추출물에서는 $82.83 \%$ 를 나타내었다(Fig. 4B).

a-Amylase 역시 a-glucosidase와 마찬가지로 추출물 농도 에 비례적으로 저해활성이 증가하였다. Fig. $5 \mathrm{~A}$ 에 나타낸바 와 같이 원형 영지버섯 추출물의 경우에는 a-glucosidase 저해활성과 동일하게 $70 \%$ 에탄올 추출물에서 저해활성이 가장 높았으며 상세하게는 $1 \mathrm{mg} / \mathrm{mL}$ 농도에서 $44.68 \%\left(40^{\circ} \mathrm{C}\right)$ 및 $28.58 \%$ (70\%)를 나타내었다. 녹각 영지버섯 추출물(1.0 $\mathrm{mg} / \mathrm{mL}$ ) 역시 a-glucosidase 저해활성과 동일하게 $40^{\circ} \mathrm{C}$ 에서 95\% 에탄올로 추출한 경우 $73.07 \%$ 로 가장 우수한 저해활 성을 나타내었고 $40^{\circ} \mathrm{C}$ 에서 $70 \%$ 에탄올로 추출한 경우에는 $62.02 \%$ 의 비교적 우수한 a-amylase 저해활성을 나타내었 다(Fig. 5B).

a-Amylase는 인체의 타액에 의해서 가장 먼저 작용을 하며 이는 소화에 있어서 대단히 중요한 효소이다. a -Glucosidase는 소장점막에 존재하는 효소로서 식품 섭취 시 탄수화물을 포도당 단위의 단당류로 분해하기 때문에 소화 및 흡수에 필수적이다. 이 탄수화물 분해효소를 저해 시킨 결과로는 포도당 흡수 억제와 혈당상승을 감소시킬 

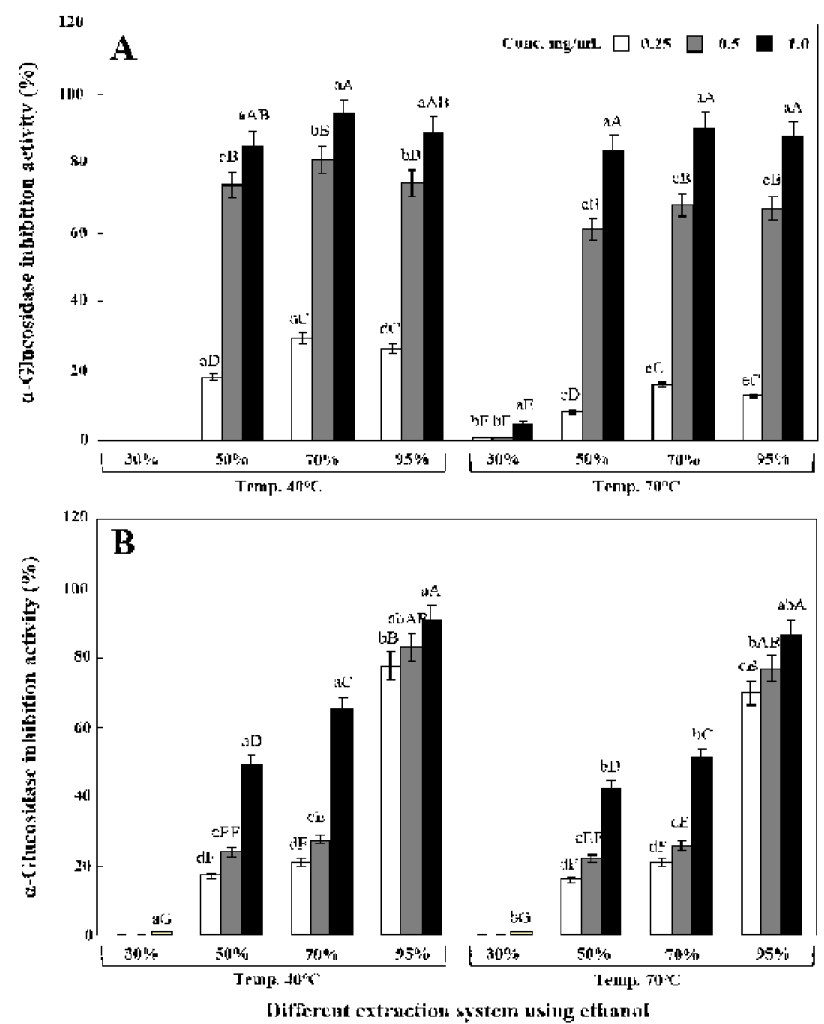

Fig. 4. Comparison of a-glucosidase inhibition activity on extracted Genoderma lucidum of two fruiting bodies from different extract system of ethanol.

A, Round type of fruiting body; B, Nokgak type of fruiting body All values are presented as the mean \pm SD of triplicate determination. All values within a column with different superscript letters of different extraction systems (EtOH concretions and temperatures) with significantly different from each other at $p<0.05$ by Duncan's multiple range test.

수 있어 당뇨 치료제로도 사용되고 있다(2). Cha 등(30)은 영지버섯, 여주 및 쓴메밀 혼합 추출물의 경우 $70 \%$ 메탄올 추출물에서 농도 의존적으로 저해활성을 보여 본 연구와 유사한 결과를 나타내었다. Kim 등(34)은 저해 활성에 관여 하는 물질로 rutin과 quercetin 등의 플라보노이드 성분이라 보고하였다. 본 연구에서는 버섯에 존재하는 $\beta$-glucan과 같은 생리활성물질의 영향으로 추출물 상태에서도 상당히 우수한 저해활성을 나타낸 것으로 추정된다.

한편, Fig. 6에 나타낸 바와 같이 pancreatic lipase 저해활 성은 $40^{\circ} \mathrm{C}$ 가 $70^{\circ} \mathrm{C}$ 보다는 활성이 약간 높았으나 원형 및 녹각 영지버섯 형태에 따른 차이점은 없었다. $40^{\circ} \mathrm{C}$ 에서 $70 \%$ 에탄올로 추출한 원형 영지버섯 추출물 $(1.0 \mathrm{mg} / \mathrm{mL})$ 의 경우 $67.56 \%$ 를 나타내었고 $70^{\circ} \mathrm{C}$ 에서 $70 \%$ 에탄올로 추출한 경우에는 $63.57 \%$ 를 나타내었다(Fig. 6A). 한편 녹각 영지버 섯 추출물의 경우 에탄올 농도가 증가할수록 저해활성이 증가하여 $95 \%$ 추출 조건에서 저해활성이 가장 우수하였고 $1 \mathrm{mg} / \mathrm{mL}$ 농도에서는 $40^{\circ} \mathrm{C}$ 에서 $70 \%$ 에탄올로 추출한 경우 $73.07 \%$ 를, $70^{\circ} \mathrm{C}$ 에서 $70 \%$ 에탄올로 추출한 경우 $62.04 \%$ 를 나타내었다(Fig. 6B).
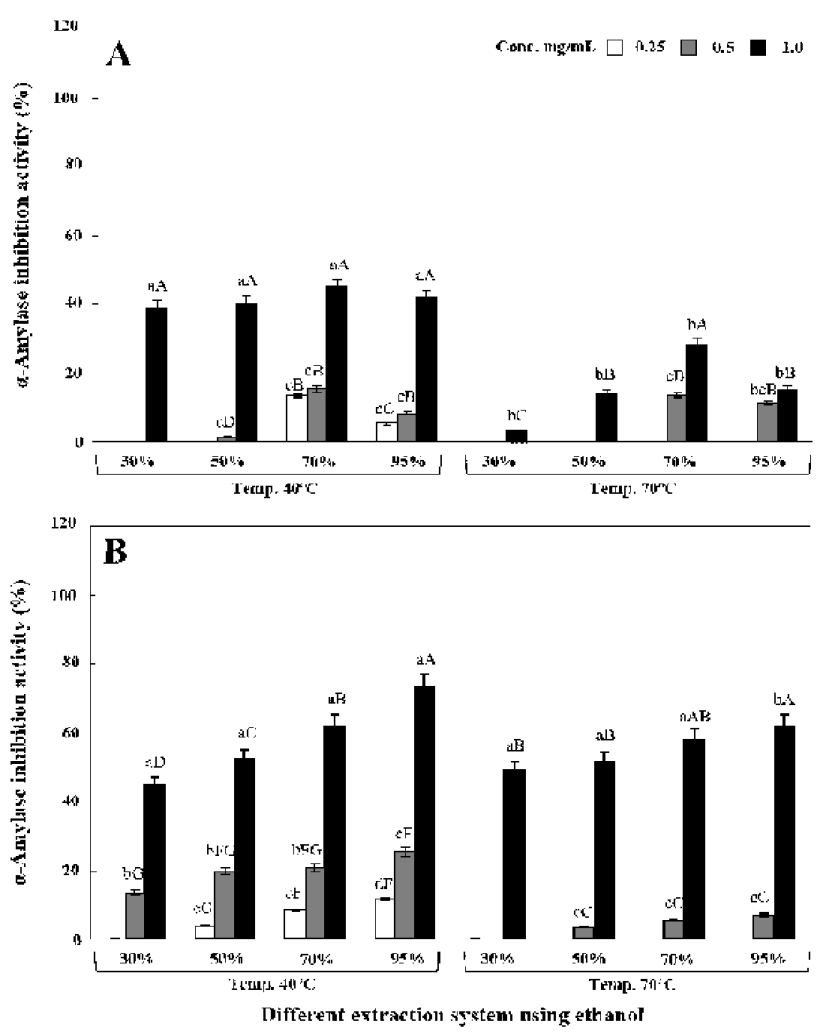

Fig. 5. Comparison of a-amylase inhibition activity on extracted Genoderma lucidum of two fruiting bodies from different extract system of ethanol.

A, Round type of fruiting body; B, Nokgak type of fruiting body.

All values are presented as the mean \pm SD of triplicate determination. All values within a column with different superscript letters of different extraction systems (EtOH concretions and temperatures) with significantly different from each other at $\mathrm{p}<0.05$ by Duncan's multiple range test.

인체에 흡수된 지방산은 triglyceride로 재합성되고 과잉 으로 존재 시 인체 여러 조직에 축적된다. 지방흡수의 중요 한 역할을 하는 lipase 저해를 통해 지방이 분해 및 축적되지 않고 체외로 배설되게 함으로써 비만에 의한 성인병을 예방 할 수가 있다(20). 보통 polyphenol성 화합물을 함유하는 천연식물 추출물은 지방세포의 지방분해를 억제하고 그 결과 지질 축적을 감소시킨다고 알려져 있다(35). Lee 등(3) 은 먹물버섯에 함유되어 있는 $\beta$-glucan을 비만이 유도된 쥐에게 식이 시켰을 때 혈중 지질 감소효과를 보고하였으며 이 외 다수 연구들 역시 상황버섯(6), 꽃송이버섯(7), 느티만 가닥버섯(9), 및 표고버섯 자실체(36)에 함유된 $\beta$-glucan을 분리 및 정제하여 실험동물에게 식이 시켜 항비만 효능을 보고하였다. 한편 polyphenol 화합물 중 catechin은 체내에 서 교감신경을 자극시켜 지방사용을 급격히 증가시킴으로 서 결과적으로 항비만 효능을 가진다는 Gupta 등(37)의 연 구결과도 존재한다. 그러나 본 연구에서의 지방분해 감소 효과는 영지버섯에 함유되어 있는 $\beta$-glucan 함량에 기인한 것으로 추정된다. 한편 Oboh 등(38)은 현재 시중에서 시판 되고 있는 경구혈당강하제인 acarbose를 positive control로 
사용하여 혈당강하 효과를 측정한 결과 a-glucosidase 저해 활성은 $66.2 \pm 0.7 \%$ 로 나타나 본 연구에서 측정한 영지버섯 추출물이 좀 더 우수하였으나 a-amylase의 경우에는 $82.8 \pm 0.7 \%$ 로 본 연구의 $40^{\circ} \mathrm{C}-95 \%$ 에탄올 추출물(원형 영지 버섯)은 약간 낮은 저해활성을 나타내었다. 이 외 Kim 등 (39)의 연구에서는 시중에 판매되고 있는 지방배출약인 Orlistat(Ro 18-0647)는 섭취된 지방의 약 $30 \%$ 를 저해할 정 도로 효능이 아주 우수하다고 보고하였으나 이에 따른 부작 용(위장장애, 과민증, 담즙분비장애 등) 역시 동반되고 있는 실정이다. 그러므로 본 연구에서 사용된 영지버섯 추출물 은 실제 사용되고 있는 지방배출약과 비교하였을 시 우수한 지방분해 효소 저해활성을 나타내므로 학술적 의미가 크다 고 사료된다. 그러나 여러 종류의 버섯들에 대한 in vitro 및 in $v i v o$ 상의 항당뇨 또는 항비만 효능은 현재 국내의 경우 많이 보고되어있으나 영지버섯에 관한 연구는 매우 부족한 것으로 조사되었다. 그러므로 향후 비만 혹은 당뇨 동물모델을 이용한 영지버섯 추출물의 in vitro와 in vivo 상의 항비만과 항당뇨 효과 등의 추가적인 검증이 필요할 것으로 판단된다.
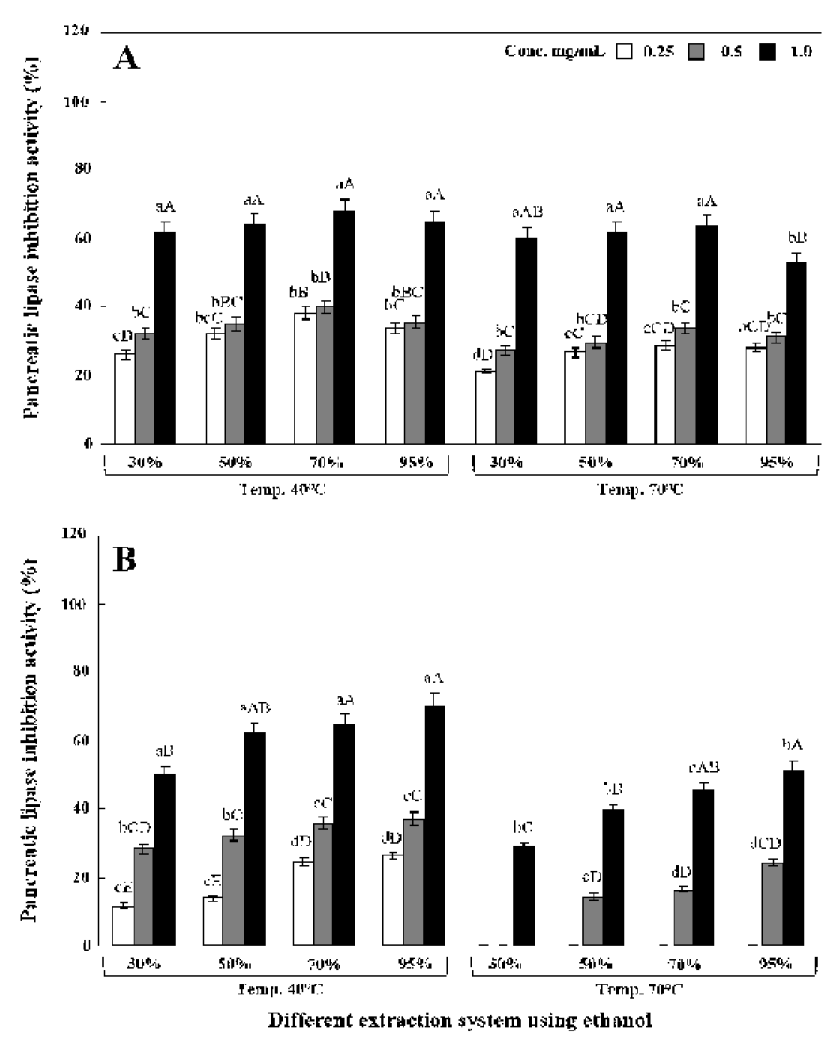

Fig. 6. Comparison of pancreatic lipase inhibition activity on extracted Genoderma lucidum of two fruiting bodies from different extract system of ethanol.

A, Round type of fruiting body; B, Nokgak type of fruiting body.

All values are presented as the mean \pm SD of triplicate determination. All values within a column with different superscript letters of different extraction systems (EtOH concretions and temperatures) with significantly different from each other at $p<0.05$ by Duncan's multiple range test.

\section{요 약}

본 연구는 영지버섯(Ganoderma lucidum)의 영양학적 특 성과 생리활성을 조사하였다. 탄수화물 함량은 원형 영지 버섯이 높았고 조회분, 조지방, 조단백질 및 무기질 함량은 녹각 영지버섯이 높았다. 주요 아미노산, 지방산, 무기질 및 수용성 비타민은 valine(원형: $11.90 \mathrm{mg} / \mathrm{g}$ 및 녹각: 17.18 $\mathrm{mg} / \mathrm{g}$ ), linoleic acid(원형: $47.56 \%$ 및 녹각: $75.68 \%$ ), 칼륨(원 형: $116.50 \mathrm{mg} / 100 \mathrm{~g}$ 및 녹각: $184.36 \mathrm{mg} / 100 \mathrm{~g}$ ) 및 비타민 $\mathrm{B}_{3}$ (원형: $1.78 \mathrm{mg} / 100 \mathrm{~g}$ 및 녹각: $1.81 \mathrm{mg} / 100 \mathrm{~g}$ ) 있었다. 한편 $\beta$-glucan 함량은 각각 $34.15 \mathrm{~g} / 100 \mathrm{~g}$ (원형)과 30.07 $\mathrm{g} / 100 \mathrm{~g}$ (녹각)로 검출되었다. 추출조건 중 $40^{\circ} \mathrm{C}-70 \%$ 에탄올 추출물에서 가장 우수한 라디칼 소거활성과 탄수화물 및 지방분해 효소 저해활성을 나타내었다. 특히, $40^{\circ} \mathrm{C}-70 \%$ 에 탄올로 추출한 원형영지버섯의 $1 \mathrm{mg} / \mathrm{mL}$ 처리 시 $\mathrm{DPPH}$, ABTS 및 hydroxyl 라디칼 소거활성과 a-glucosidase, a -amylase 및 pancreatic lipase 저해활성은 각각 $92.85,99.74$, $58.09,89.68,44.68,67.56 \%$ 로 나타났다.

\section{감사의 글}

본 연구는 농림축산식품부 농생명산업기술개발사업(과 제번호: 314021-03) 및 농림축산식품부 고부가가치식품개 발사업(과제번호: 116009-3)에 의해 이루어진 결과입니다.

\section{References}

1. Choi SJ, Lee YS, Kim JK, Kim JK, Lim SS (2010) Physiological activities of extract from edible mushrooms. J Korean Soc Food Sci Nutr, 39, 1087-1096

2. Lee SY, Kim JH, Park JM, Lee IC, Lee JY (2014) Antioxidant activity and inhibition activity against a -amylase and a-glucosidase of Smilax China L. Korean J Food Preserv, 21, 254-263

3. Lee SJ, Park HJ, Song YO, Jang SH, Goo AJ, Ko Y, Cho JH (2014) Antioxidant activity and anti-obesity effect of Coprinus comatus in Zucker rat (fa/fa). Korean J Vet Serv, 37, 51-58

4. Joo OS (2008) Chemical components and physiological activities of Neungee Mushroom (Sarcodon aspratus). Korean J Food Preserv, 15, 864-871

5. Lee HJ, Do JR, Jung SK, Kim HK (2014) Physiological properties of Sarcodon aspratus extracts by ethanol concentration. J Korean Soc Food Sci Nutr, 43, 656-660

6. Lee JK, Song JH, Lee JS (2010) Purification of 
anti-obesity lipase inhibitor from the fruiting body of Phellinus linteus. Kor J Mycol, 38, 57-61

7. Lee MR, Hou JG, Begum S, Wang YB, Oh DS, Wi AJ, Yoon BS, Sung CK (2014) Anti-obesity effects of Sparassis crispa on high-fat diet-induced obese mice. J Life Sci, 24, 952-958

8. Ryu HJ, Um MY, Ahn JY, Jung CH, Huh D, Kim TW, Ha TY (2011) Anti-obesity effect of Hypsizigus marmoreus in high fat-fed mice. J Korean Soc Food Sci Nutr, 40, 1708-1714

9. Yang BK, Kim DH, Song CH (2002) Production of Lentinus edodes mycelia in submerged culture and it's hypoglycemic effect in diabetic rats. Kor J Mycol, 30, 131-135

10. Park JS (2013) Effect on the inhibition of pancreatic lipase and lipid metabolism of Zanthoxylum poperitum extracts. Korean J Food Nutr, 26, 615-619

11. Yoon DE, Park YJ, Kwon OC, Nam JY, Kim HI, Yoo YB, Kong WS, Lee CS (2013) Study on HPLC conditions for chemotaxonomy of Ganoderma species. J Mushroom Sci Prod, 11, 107-110

12. Cho JH, Noh HJ, Kang DH, Lee JY, Lee MJ, Park HS, Sung GH, Jhune CS (2012) Comparative analysis of amino acid contents of the fruiting bodies in Ganoderma spp.. J Mushroom Sci Prod, 10, 208-215

13. Cho JH, Lee JY, Lee MJ, Oh HN, Kang DH, Jhune CS (2013) Comparative analysis of useful $\beta$-glucan and polyphenol in the fruiting bodies of Ganoderma spp.. J Mushroom Sci Prod, 11, 164-170

14. Korea Food Drug Administration. http://fse.foodnara.go.kr /residue/RS/jsp/menu_02_01_01.jsp. (accessed 2010).

15. Shin EC, Hwang CE, Lee BW, Kim HT, Ko JM, Baek IY, Lee YB, Choi JS, Cho EJ, Seo WT, Cho KM (2012) Chemometric approach to fatty acid profiles in soybean cultivars by principal component analysis (PCA). Prev Nutr Food Sci, 17, 184-191

16. Folin O Denis W (1912) On phosphotungsticphosphomolybdic compounds as color reagents. J Biol Chem, 12, 239-243

17. Jia Z, Tang M, Wu J (1999) The determination of flavonoid contents in mulberry and their scavenging effects on superoxide radicals. Food Chem, 64, 555-559

18. Hwang CE, An MJ, Lee HY, Lee BW, Kim HT, Ko JM, Baek IY, Seo WT, Cho KM (2014) Potential probiotic Lactobacillus plantarum P1201 to produce soy-yogurt with enhanced antioxidant activity. Korean J Food Sci Technol, 46, 556-565
19. Sin SM, Mok SY, Lee SH, Cho KM, Cho EJ, Kim HY (2011) Protective effect of Bitter Melon (Momordica charantia) against oxidative stress. Cancer Prev Res, 16, 86-92

20. Park JH, Baek MR, Lee BH, Yon GH, Ryu SY, Kim YS, Park SU, Hong KS (2009) a-Glucosidase and a -amylase inhibitory activity of compounds from roots extract of Pueraria thunbergiana. Korean J Med Crop Sci, 17, 357-362

21. Kwon OJ, Lee HY, Kim TH, Kim SG (2014) Antioxidant and pancreatic lipase inhibitory activities of Anemarrhena asphodeloides. Korean J Food Preserv, 21, 421-426

22. Lee SK, Yoo YJ, Kim CS (1989) Studies on the chemical components in Ganoderma lucidum. Korean J Food Sci Technol, 21, 890-894

23. Lee HA, Kim BK, Hyun JW (2004) Free amino acids and their derivatives of Ganoderma lucidum. Environ Muta Carcino, 24, 67-72

24. Lee KJ, Yun IJ, Kim HY, Park YH, Ham HJ, Park YH, Joo JH, Lim SH, Kim KH (2009) Analysis of general components and vitamin and mineral contents of the mushroom Agrocybe chaxingu. Korean J Food Preserv, 16, 549-553

25. Lee SH, Kim NW, Shin SR (2003) Studies on the nutritional components of mushroom (Sarcodon aspratus). Korean J Food Preserv, 10, 65-69

26. Kim JH, Lee SC, Ju YC (2007) Effect of far-infrared irradiation on the antioxidant activity of extracts from Phellinus igniarius and Ganoderma lucidum. Korean J Food Sci Technol, 39, 386-389

27. Jeong GL, Shin HJ, Cha WS (2006) Analysis of amino acids, vitamins and minerals of fruiting body of Fanitopsis pinicola. J Life Sci, 16, 1123-1126

28. Seo YC, No RH, Kwon HS, Lee HY (2013) Enhancement of the cosmeceutical activity by nano-encapsulation of thiamine di-lauryl sulfate (TDS) with antimicrobial efficacy. J Soc Cosmet Sci Korea, 39, 205-213

29. Oh SI Lee MS (2005) Antioxidant and antimutagenic effects of Ganoderma lucidum krast extracts. Korean J Food Nutr, 18, 54-62

30. Hur H (2008) Analysis of biological activities of medicinal mushrooms. Kor J Pharmacogn, 39, 265-269

31. Cha JY, Jin JS, Cho YS (2011) Biological activity of methanolic extract from Ganoderma lucidum, Momordica charantia, Fagopyrum tataricum, and their mixtures. J Life Sci, 21, 1016-1024

32. Wang MF, Li JG, Rangarajan MR, Yu Shao J, LaVoie 
EM, Hung TC, Ho CT (1998) Antioxidative phenolic compounds from sage (Salvia officinalis). J Agric Food Chem, 46, 4869-4873

33. Cheung LM, Cheung CK, Vincent ECO (2003) Antioxidant activity and total phenolics of edible mushroom extracts. Food Chem, 81, 249-255

34. Shi M, Zhang Z, Yang Y (2013) Antioxidant and immunoregulatory activity of Ganoderma lucidum polysaccharide (GLP). Carbohydr polym, 95, 200-206

35. Kim JE, Joo SJ, Seo JH, Lee SP (2009) Antioxidant and a-glucosidase inhibitory effect of tartary buckwheat extract obtained by the treatment of different solvents and enzymes. J Korean Soc Food Sci Nutr, 38, 989-995

36. Park YJ, Nam JY, Yoon DE, Kwon OC, Kim HI, Yoo YB, Kong WS, Lee CS (2013) Comparison of anti- inflammatory, antioxidant and anti-allergic effects of Ganoderma species mycelial extracts. J Mushroom Sci Prod, 11, 111-115

37. Kim SJ, Heo MY, Bae KH, Kang SS, Kim HP (2003) Tyrosinase inhibitory activity of plant extract (III): fatty acid Korean indigenous plants. J Appl Phamacol, 11, 245-248

38. Oboh G, Ogunsuyi OB, Ogunbadejo MD, Adefegha SA (2016) Influence of gallic acid on a-amylase and a -glucosidase inhibitory properties of acarbose. J Food Drug Anal, 24, 627-634

39. Kim MS, Kim BY Park CS, Yoon BD, Ahn SC, Oh WK Ahn JS (2006) Inhibitory effect of Thujae orientalis semen extract on pancreatic lipase activity. J Life Sci, $16,328-332$ 